\title{
İKTİDARIN GÖLGESİNDE İNANÇ VE YABANCILASSMA: THE DEVILS
}

\author{
Eşref Akmeşe \\ Mikail Boz \\ Hüseyin Gençalp
}

\begin{abstract}
Öz
İnsan ve toplumsal yaşamının örüntülenmesi birbiriyle ilişkili çok boyutlu bir süreçtir. Bireyin inanç, değer ve gündelik yaşam edimleri kapsayıcı bir iktidar mekanizmasının gölgesinde sürekli olarak düzenlenmektedir. Güç, iktidar ve sınıf mücadelelerinin olduğu her tarihsel dönemde direniş pratiklerinin ortaya çıkması, mücadele süreçlerinin çelişkisiz işlemediğini gösterdiği gibi iktidarların mutlak olamayacağını da ortaya koymaktadır. Bu doğrultuda insanlık tarihi oldukça zengin bir çelişki, mücadele ve ilişkiler sistemi sunmaktadır. Bireyi ve toplumu yakından ilgilendiren tarihsel olay ve olguların filmlerde ele alınması ise sıklıkla karşılaşılan bir durumdur. Dolayısıyla belirli bir tarihsel olgunun sinema filmlerinde nasıl ve ne şekilde kendine yer bulduğunu anlamak önemlidir. Bu çalışmada, Ken Russell'ın The Devils (1971) adlı filmi dönemin güç mücadeleleri, iktidar yapısı ve Katolik Kilisesi'nin, bireylerin inanç ve yaşam pratikleri üzerinde ne türden denetim yapıları kurduğu, bu bastırma ve düzenleme mekanizmalarının hangi direniş biçimlerini yarattığını anlamak amacıyla nitel yaklaşımla, betimsel analize tabi tutulmuştur. Sonuç olarak filmde bastırılmış cinsellik ve inanç özgürlüğü gibi konuların Hıristiyanlığın sert bir eleştirisiyle sunulduğu, Katolisizm ve onun normları üzerindeki mücadelenin büyük ölçüde siyasi iktidar mücadeleleriyle ilişkili biçimde ortaya konulduğu görülmüştür.
\end{abstract}

Anahtar Sözcükler: Ken Russell, The Devils, sinema, iktidar, inanç, yabancılaşma, engizisyon.

\footnotetext{
Geliş Tarihi I Received: 10.11.2018 • Kabul Tarihi I Accepted: 23.01.2019

Eşref Akmeşe, Arş. Gör., İnönü Üniversitesi lletişim Fakültesi

Mikail Boz, Dr. Öğr. Üyesi, Bozok Üniversitesi Iletişim Fakültesi

Hüseyin Gençalp, Arş. Gör., Trabzon Üniversitesi lletişim Fakültesi
}

E. Akmeşe ORCID: https://orcid.org/0000-0003-0906-8928 • E-Posta: esrefakmese@gmail.com

M. Boz ORCID: https://orcid.org/0000-0003-4276-1521 • E-Posta: bozmikail@gmail.com

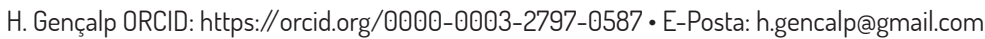

Akmeşe, E., Boz, M. \& Gençalp, H. (2019). İktidarın Gölgesinde İnanç ve Yabancılaşma:

The Devils. sinecine, 10(1), 61-84. 


\title{
FAITH AND ALIENATION IN THE SHADOW OF POWER: THE DEVILS
}

\begin{abstract}
The formation of patterns of people and their social lives is a multi-dimensional process. The beliefs, values, and daily practices of individuals are governed through mechanisms of comprehensive power. Resistance has emerged in every historical period in which struggles of power and class have been manifest. Absolute power is impossible to achieve; no struggle proceeds without opposition. In this study, Ken Russell's The Devils (1971) is analyzed by the descriptive quantitative research method in an attempt to understand which mechanisms were used by the power structure and the Catholic Church to control a person's life and beliefs, and, concurrently, what kind of resistance arose to counter repression and regulation. In conclusion, it is seen that Russell employs motifs of suppressed sexuality and freedom of belief to fashion a harsh critique of Christianity. The struggle against Catholicism and its norms is expressed as a struggle against political power.
\end{abstract}

Keywords: Ken Russell, The Devils, cinema, power, belief, alienation, Inquisition. 


\section{Giriş}

Sinema, insanlık tarihi göz önüne alındığında oldukça yeni bir sanat dalıdır. Bununla birlikte neredeyse insanlığın başından geçen bütün serüvenler sinema filmlerine işlenmektedir. Bu durum kaçınılmaz olarak insanlık tarihinden soyutlanamaz olan inanç pratiklerini de kapsamaktadır. İnanç sistemleri ve bu sistemler içinde yer alan bireylerin yaşam pratikleri her zaman destan, mit, öykü, roman vb. anlatılara konu teşkil etmiştir. Sinema filmlerine bakıldığında, pek çok yapımın arka planında dinsellik, kutsallık ve bunlara yönelik ihlallerin cezalandırılması olgusunun yer aldığını söylemek mümkündür.

İnanç sistemleri ve bu sistemlere içkin birer unsur olan inanç pratikleri dönemsel farklllıklar gösterebilmektedir. Bu farklar temel olarak içinde yaşanılan toplumun özelliklerinden ve kültürel yapısından kaynaklanmaktadır. Toplumsal yaşamın belirli bir düzene oturtulmasını amaçlayan ve bireyler için belli başlı bazı ahlak ve davranış kalıpları belirleyen inanç sistemleri, birtakım tabu ve kutsallıkları da üretmektedir. $\mathrm{Bu}$ türden dokunulmaz ve tartışılmaz kabul edilen değerler geçmişten günümüze çeşitli sanatsal anlatı formlarında farklı biçimlerde ve sürekli olarak işlenmiştir. Bahsi geçen bu unsurların aktarımında sanatsal ürünlerin kullanılması ve bu durumun süreklilik göstermesi ise temel olarak inanç sistemlerinin hayatın gerekliliklerinden beslenmesi ve egemen ideolojik kalıpların sanat aracılığıyla yeniden üretilmesiyle ilişkilidir. Bu durum engellenemez biçimde kendi karşıtını da doğurmuş, inanç sistemlerinden üretilen yaşam pratiklerinin eleştirisi de çeşitli sanatsal anlatılarda kendine yer bulmuştur.

Genel olarak bu tür anlatılara bakıldığında, var olan düzenin bozulması ya da çeşitli kuralların ihlal edilmesinin bir çıkış noktası olduğu görülmektedir. Bu bağlamda pek çok anlatı, bir yasağın ihlal edilmesi, bir tabunun yıkılması veya aykırı bir bireyin rutini bozan davranışları üzerinde şekillenmektedir. Anlatılarda dinleyici, izleyici veya okurlara ihlal edilen kuralların olumsuz sonuçları gösterilmekte ve böylece var olan düzen ve düzenin savunduğu ahlaki yapı olumlanmaktadır. Bu durum aynı zamanda anlatıyı alımlayan bireylere bir ödev ahlakının sunulduğu ve çeşitli kültürel norm ve değerlerin aktarıldığı bir süreci de ifade etmektedir. 
Bir toplumda inanç sistemleri tarafından tabu veya kutsal olarak kabul edilen kişi, nesne, oluş ve olgularla ilişkili bir tartışma yürütülmesi, bu tabuların incelenmesi ve irdelenmesi kolay değildir. Modern bir sanat olan sinema, görsel ve işitsel anlatı yapısıyla inanç sistemlerinin eleştirel olarak ele alınabildiği önemli bir mecra olarak görülmektedir.

Pek çok konuda olduğu gibi, din üzerine yapılan tartışmalar da belli düzeylerde bir kategorileştirmeye dönüşmektedir. Muhafazakâr, radikal, llımlı gibi sıfatlar herhangi bir kişiye ya da gruba dönük tanımlamalardan daha fazlasını ifade etmekte ve dinin özüne ilişkin bir tartışmayı canlı tutmaktadır. Eliade dinlerin sıklıkla "Altın Çağ" olarak ifade edilen bir "başlangıç durumu" resmettiğini belirtmektedir (2001, s. 84-85, 92). Bu çağdan sonraki tüm çağlar ise belli ölçülerde geçmişe özlemle bakan, geçmişteki güzel günlerin yeniden gelmesini isteyen, insanların dinsel gerekliliklerinden hızla uzaklaştıklarını savlayan görüşlerin hâkim olduğu dönemler olarak görülmektedir. Şüphesiz bu düşünceler en fazla kapitalizmle yükselişe geçmiştir. Kentleşme, iletişim ve ulaşım teknolojilerinde gelişme, kitlesel üretimin getirdiği tüketim biçimleri, toplumsal ilişkilerde içedönüklük, yalnızlaşma ve toplumun giderek dinsel özden uzaklaştığına ilişkin görüşler, kendi içsel mantığıyla eski güzel günleri canlı tutma özlemini de ifade etmektedir. Geçmişe özlem düşüncesinin doğal sonucu ise yaşanılan dönemin -kötülük çağı- kıyametin arifesi olarak görülmeye başlanmasıdır. Bu duruma bağlı duygusal motivasyon çifte değerli bir anlam taşır; toplu bir yok oluş ve diriliş olarak kıyamet, yaşama duyulan bir memnuniyetsizliğin ifadesi olarak değişim isteğinin dışavurumu olurken, nostaljik altın çağa dönüş bu değişimden kaçınmanın genel yansıması halini almaktadır. Her iki durum da yaşanılan ânla ilgili genel bir korku ve kaygının dışavurumu olarak semptomatik bir özellik göstermektedir.

Bu çalışmada Ken Russell'ın The Devils (Şeytanlar, 1971) filmi tarihsel bir perspektifle incelenecektir. The Devils'da Russell tarihsel bir dönemi ve toplumu ele almakla birlikte film temel olarak inançlar, yasaklar, tabular ve inanç sistemlerinin bireyler üzerindeki etkileri ortak paydasında kesişen özellikler göstermektedir. 1968 öğrenci eylemlerinin yükselişe geçtiği bir süreçte yapılmış olan The Devils filmi, Avrupa'da 30 Yll Savaşları'nın devam ettiği tarihsel dönemi ele almaktadır. Dinin ve dinsel kurumların egemen bir şekilde gündelik yaşamı etkisi altına aldığı ve her alanın dinsel dogmalarla belirlendiği bir tarihsel kesiti sinema perdesine yansıtan film, insan, inanç ve yaşam ekseninde inanca dayalı dogmaların 
yaşama müdahalesinin vahametini ortaya koymaktadır. Bu yönüyle The Devils, tarihsel bir süreci anlamak ve tarihselin güncel olanla ilişkisini okumak bağlamında irdelenmeyi hak etmektedir. Çalışmada öncelikle filmin analizine temel teşkil edecek biçimde inanç, tabu, kaygı-korku, yabancılaşma gibi birbiriyle ilişkili kavramlar, Nietzsche'nin Hristiyanlık eleştirisiyle bağlantılı biçimde sunulacak, filme temel olan Loudun rahibelerinin yaşadığı durum hakkında bilgi verilecektir. The Devils'in analizi için, sosyal bilimler alanında bütüncül bir bakışa imkân tanıyan ve film anlatılarındaki örüntüleri metinsel ve bağlamsal düzeyde ortaya çıkarmayı olanaklı kılan niteliksel içerik analizi kullanılacaktır.

\section{İnanç, Tabu, Kaygı-Korku}

Gordon Marshall dini, "kutsal fikrine dayalı olan ve müminleri bir sosyo-dinsel topluluk içinde birleştiren bir inançlar, semboller ve pratikler (örneğin, ritüeller) kümesi" (2005, s. 156) olarak tanımlamaktadır. İnanç ise "görgü, bilgi alanını aşan bağlanış tarzı" (Ülken, 1969, s. 146) olarak bir düşünceye, kişiye ya da din bağlamında özelleştirilirse evreni yaratan ve yöneten tanrısal bir gücün varlığına duyulan bağllık olarak ifade edilmektedir. İnancın bu biçiminde, öznel olarak kabul edilen ama nesnel olarak yeterli olmayan gerekçelerle bir yöneliş ve açıklama bulunmaktadır. İnancın temel kaynaklarından biri birlik düşüncesidir. Kişinin kendisini, dünyayı ve tüm evreni daha büyük bir amaç için bir araya gelmiş bir bütün olarak görmesi, bir nedensellik istenci olarak geçmiş zamanı, amaçlılık olarak da gelecek zamanı anlamlı kılmaktadır. Bu yolla neden ve amaç arasında kalan birey için yaşamın kendisinin bir sınav olması anlaşılır bir durumdur; inançlı kişi bu ikisi arasında kendisini bir köprü ve bunları birbirine bağlayan özne olarak görmektedir. Dolayısıyla varlığı, nedenini ve sonucu anlamlı kılanın öznenin edimleri olduğu sonucuna ulaşılmaktadır. Simmel'in vurguladığı gibi inanç sadece Tanrı'nın varlığını kabul etmek değildir; inanç kişinin Tanrı'yla kurduğu içsel bir ilişkiyi, duygusal olarak bağlılığı ve hayatı şekillendirirken onun kurallarına göre hareket etmesini gerektirmektedir (Simmel, 2009, s. 307-309).

İnanç kavramını kutsaldan, kutsal dışından ve tabulardan soyutlamanın mümkün olmadığı görülmektedir. Tabu Polinezya diline ait bir sözcüktür ve kutsal, kutsanmiş, tekinsiz, tehlikeli, yasak, murdar anlamlarına gelmektedir (Freud, 2012, s. 69). Günümüzde "toplum düzeyinde ve çoğunlukla kutsal sayılan şeyleri referans alarak, bazı şeylerin, insanların ya da hareketlerin yasaklanmasının, bunlara dokunulamamasının ya da 
sözünün bile edilememesinin kastedildiği daha geniş bir kullanım alanı vardır" (Marshall, 2005, s. 712). Freud ensest, yamyamllk ve öldürme istencini en eski üç içgüdü, bunlara ilişkin tabuları da uygarlığın kurucu yasakları olarak tanımlamaktadır. Freud'a göre, insan gelişimine uygun olarak dışsal baskı içselleştirilmektedir (Freud, 2004, s. 174-175). İçgüdüleri bastırma sonucu gelişen bu kurallar duygulanım düzeyinde de yoğun bir denetimi getirmekte ve ortaya çıkan çatışma çözümlenmediğinde kaygı, korku gibi semptomlarla, sağlıksız bir durum ortaya çıkmaktadır.

Kierkegaard kaygıyı insanın varoluşsal olarak sahip olduğu bir olgu olarak görmekte ve onu baş dönmesine benzetmektedir. Buna göre korkulan şeyin varlığı kadar bu şeyi fark etmek, bakışı veya duyuları onu alg1lamak adına bu nesneye yöneltmek de kaygıya neden olur. Bu bakımdan kaygı özgürlükle yakın ilişki içindedir (Kierkegaard, 2013, s. 56). Kaynağının belirsizliği, daha az şiddetli oluşu ve daha uzun süre devam etmesiyle korkudan ayrılan kaygı, kişiden toplumsal desteğin çekilmesi, olumsuz bir sonucu beklemek, iç çelişki ve belirsizlik gibi sebepleri içermektedir (Cüceloğlu, 2006, s. 278-279). Kaygı bu belirsizlik nedeniyle yaşamın olumsallığı içinde büyür ve ağırlıkla gelecek zamanın bir dışavurumu halini alır. Buna göre bir bireyin "olacak şeyler" üzerinden, yapılanların hangi oluşa gideceğini bilmemesinden kaynaklanan bir kaygı ve belirsizlik içinde yaşaması söz konusudur. Geçmişe ilişkin kaygı ise özünde geçmişteki durum ya da davranışın gelecekte yaratacağı olası etkinin sonuçlarından ve yinelenmesinden duyulan bir kaygıdır (Kierkegaard, 2013, s. 88) ve dini anlamda ele alındığında günah kavramıyla yakın ilişki içindedir. Geçmişteki edimlerin kefaretinin ödenmesi gerektiği ve bunun hem dünyadaki yaşamda hem de ahirette bir yaptırımının olacağı fikri, kişiyi inancına bağlı tutar ve inancın gerektirdiği ritüelleri yerine getirme yönünde itici bir rol oynar. Kaygı ve korkunun, toplumsal yaşamdaki tabuların ihlali, toplum tarafindan kabul edilmeme gibi sebeplerle bir sonuç; toplumsal yaşamı algılayış ile onu belirleme ve yeniden üretimine katkıda (kendi ürettiği toplumsal ilişkilere yabancılaşma) bulunma bakımından bir neden, dolayısıyla diyalektik bir ilişkinin neticesi olduğunu söylemek mümkündür. Bu bakımdan kendi gerçekliğini nesneleştiren, dışsallaştıran, onun oluşumuna katkı sunan kişi, yarattığı bu toplumsal ve fiziki gerçekliğin kendi üzerinde yarattığı duygulanım süreçlerinin olumsuz sonuçlarıyla kaygı ve korku gibi duygularla başa çıkmaya çalışmaktadır.

İnanç, sorgulamayı ve eleştirel düşünceyi dışlayan bir niteliğe sahiptir; bu yönüyle tabu ve dogmatik düşüncelerle beslendiği görülmektedir. 
Tabuların egemen olduğu bir düşünsel atmosfer kaçınılmaz olarak kaygı ve korkuları kuvvetlendirip derinleştirmektedir. Bu durum ise gerçeklikten kopuşu ve sağlıklı olmayan bir durumu ifade eden yabancılaşmayı doğurur. Yabancılaşma genel bir toplumsal duruma dönüştüğünde ise yaşamin birçok alanında çöküş süreci hayata egemen olmaya başlamaktadır. İnanç, dogmatizm ve yabancılaşma süreci topluma egemen olan iktidar ilişkilerinden soyutlanamaz. Bu temelden hareketle, egemen ideolojinin egemenlerin ideolojisi olduğu ifade eden Marksist kabul (Marx ve Engels, 2013, s. 52) çerçevesinde, inanç temelli çatışmaların aslında politik eksende geliştiği anlaşılmaktadır. Bu durum başta ekonomi olmak üzere bütün alt yapı ve üst yapı ilişkilerinde inancın önemli bir ideolojik araç olarak kabul edilmesi gereğini açıklamaktadır. Bu düzeyde işlevsel bir aracın yabancılaşma olgusuyla ilişkisinin daha anlaşılır bir biçimde ortaya konulması açısından yabancılaşma olgusunun açıklanması gerekmektedir.

\section{Yabancılaşma ve Hristiyanlık}

Bir olgu olarak insanlık tarihiyle yaşıt olduğu söylenebilecek yabancılaşmanın kavramsal düzeydeki kullanımlarının, teolojiden psikiyatriye, felsefeden iktisat bilimine uzanan oldukça geniş bir kapsama sahip olduğu görülmektedir. Dünya yazın tarihi içinde birkaç yüzyıldır birçok metin içinde yer alan ve farklı biçimlerde ifade edilebilen yabancılaşma, en genel çerçevesiyle tanımlandığında "bireylerin birbirlerinden ya da belirli bir ortam veya süreçten uzaklaşmalarını anlatır" (Marshall, 2005, s. 798). Burada verilen genelleyici ve kapsayıcı tanımdan anlaşılacağı üzere yabancılaşma öncelikle bir durum veya gerçeklikten uzaklaşmayı ifade etmektedir. Yabancılaşma daha özgül biçimiyle kişinin ürettiği şeylerle arasındaki bağın kopması ve aradaki diyalektik ilişkinin görülmemesi biçiminde ifade edilebilir:

Yabancılaşma kavramı, tarih boyunca, çeşitli felsefe ve teoloji sistemlerinde önemli bir rol oynamıştır. Metafizik sistemlerde "Hakikat"in ve "Mutlak"ın, yani Tanrı'nın kendi varlığından uzaklaştığından, kendine yabancı ve aykırı bir şekilde ortaya çıktığından söz edilir. "Düşüş", "Alçalma" ya da "Sudûr" etme sözleri, yabancılaşma kavramını dile getirmek için kullanılmış kelimelerdir. İslam felsefesinde ve tasavvufta aynı kavrama, dinî ve mistik bir kisveye bürünmüş halde rastlanmaktadır. Yabancılaşma kavramı, zamanla, mistik ve dinî anlamından sıyrılmış ve özellikle Hegel'in felsefesinde rasyonel (aklî) bir anlam kazanmiştır (Hilav, 2008, s. 47). 
Hegel'e göre yabancılaşma süreci, bilincin ya da zihnin kendi dışına çıkması ve kendini kendi dışında farklı bir şey olarak algılamasıdır (Timuçin, 2004, s. 497). Hegel'in felsefesini eleştirme bağlamında yabanc1laşmayı ele alan bir düşünür olan Ludwig Andreas Feuerbach (1804-1872), Hegel'in felsefesinin temelini oluşturan Mutlak Tin'in kendine yabancılaşarak insanın ortaya çıktığı fikrine karşı, insanın kendine yabancılaşarak Mutlak Tin'i yarattığı fikrini ileri sürer. Feuerbach dinin "temelde insanın kendi yeteneklerini, güçlerini, isteklerini, duygularını bir varlığa yükleyip ona boyun eğmesinden başka bir şey" olmadığını belirtmektedir (Öz, 2006, s. 597). Bu açıdan bakıldığında Feuerbach için, din insanın yaşadığı, daha doğrusu kendine yaşattığı bir çeşit yanılsamadan başka bir şey değildir. Hegel ve Feuerbach sonrası dönemde yabancılaşma Karl Marx'ın (1818-1883) da üzerinde durduğu önemli bir sorunsal haline gelmiştir. Marksist düşünce sistemi içinde, yabancılaşmış emek bağlamında, insanın yabancılaşmasına önemli bir yer atfeden Marx için, yabancılaşma; insanın kendinden uzaklaşması ve yaratıcı eyleminin körelmesidir. Yabancılaşan insan kendi eylemleri ve emeği üzerinde söz hakkını yitirir; kendisini ve öteki bireyleri insan olarak göremez, öyle ki kendisinin de bir parçası olduğu toplum ve doğayla insani anlamda sağlıklı bir ilişki kuramaz (Marx, 2011, s.147-148).

Marksist yabancılaşma kuramını psikanalitik bir anlayış, çerçevesinde geliştirmeye çalışan Erich Fromm'a göre, yabancılaşmaya dair ilk pratik izlere, puta tapıcılık bağlamında Eski Ahit'te rastlanır. İnsanların, emek sarf ederek, kendi yaratımsal yeteneklerini kullanarak ürettikleri nesnelere boyun eğmeleri, tapınmaları ve kendi yaratımlarından koparak uzaklaşmaları karşı karşıya kaldıkları yabancılaşma gerçekliğini ortaya koyar. Bununla birlikte modern toplumda, yabancılaşma yeni bir aşamaya gelmiştir. İnsanın işiyle, kendisiyle, öteki insanlarla, devletle ve hatta tükettiği nesnelerle olan ilişkileri değişmiş, yabancılaşma tüm bu ilişkileri belirleyecek konuma gelmiştir. Bu aşamada insan ilk kez bütünüyle kendi eliyle ürettiği nesnelerden oluşan bir dünya yaratmıştır. $\mathrm{Bu}$ tekniği yaratan insan, yarattığı tekniği yönetmek adına, toplumsal açıdan karmaşlk bir sistem kurmuştur. Ne var ki; insan kendi yaratımı olan şeylerin egemenliği altına girmiş, kendi yaratımları onun üstüne çıkmıştır (2006, s. 117- 120).

Batı düşünce tarihinde Hristiyanlığa ve Hristiyanlığın neden olduğu yabancılaşma olgusuna karşı belki de en sert eleştiriler kuşaklar boyu din adamları yetiştiren bir ailenin mensubu olan Alman filozof Friedri- 
ch Wilhelm Nietzsche'den (1844-1900) gelmiştir. Robinson'a göre, Nietzsche için Hristiyanlık, kökleri Sokrates'e kadar giden, kendine özgü bir düşünce sisteminin en kötücül aşamasını ifade etmektedir (2000, s. 10). Nietzsche bunu şu şekilde ifade eder: "Hristiyanlık, diyorum, tek büyük lanet, tek büyük içsel yozluk, hiçbir aracın yeterince zehirli, gizli, yeraltı, küçük gelmediği tek büyük intikam içgüdüsüdür, -diyorum, tek silinmez utanç lekesi, insanlığın..." (2008, s. 98). Robinson'a göre, Batı Avrupalıları Hristiyan değerlerin artık geçerliliğini yitirdiği gerçeğiyle yüzleşmeye çağıran (2000, s. 6) Nietzsche, Hristiyanlığı dünyadaki yaşamı olumsuz göstermek ve sadece öte dünya için bir geçiş süreci olarak değersiz kılmakla eleştirmektedir. Nietzsche'ye göre Dünүa Hristiyanlıkta bir sövgü sözcügüüür (2004, s. 52).

Ludovici'ye göre, Metafizikle ve Hristiyan dogmalarıyla beraber Nietzsche kendi çağındaki gelenekleri yıkan, ikonaklast rasyonalistlerden çok daha öteye bir adım atmıştır. Hristiyan değerlerini sert bir biçimde eleştiren Nietzsche onların da yalnızca diğer değerler gibi, güç için mücadele eden belli bir insan türünün elindeki bir silah olduğunu ifade etmiştir (2011, s. 58). Görüldüğü gibi Nietzsche Hristiyanlığın değerlerini güç istenci ile ilişkili olarak açıklamakta ve manevi niteliklerinden soyutlamaktadır.

Buraya kadar, açıklanan kuramsal yaklaşımlardan anlaşılacağı üzere yabancılaşma, kişinin karmaşık birçok diş etkenin kendi üzerinde yarattığı etkilerle oluşan ve bireyin kendi kendine deneyimlediği bir çeşit kendine uzaklaşma, kendi gerçekliğini idrak edememe durumu olarak ifade edilebilir. Bu çalışmada tarihsel süreç içerisinde geliştirilen yabancılaşma kuramlarına yaklaşımları ana hatlarıyla açıklanan çeşitli düşünürler, kuşkusuz kendi düşünce sistemleri içinde yabancılaşma sorununun farklı çözümlerini de geliştirmişlerdir. Buna karşın ele alınan filmde yaşanan yabancılaşma biçimlerini ortaya koymakla yetinilecektir, dolayısıyla yabancılaşma sorununa çözüm önerileri sunmak bu çalışmanın amaçları dışındadır.

\section{Filme Temel Olan Tarihsel Konjonktür}

Yönetmenliği Ken Russell'ın yaptığı The Devils filmini ve eserde betimlenen 17. yüzyıl Fransa'sının toplumsal dinamiklerini daha iyi anlamak için, 16. ve 17. yüzyılda Avrupa'da yaşanan siyasal ve sosyal gelişmeleri ve bunların Avrupa toplumu üzerindeki etkilerini gözden geçirmek gerekmektedir. 
Kutsal Roma İmparatorluğu ve Papa tarafından yönlendirilen Hristiyanlık, Hristiyanlığın geniş yetki alanına karşı çıkan ulusal monarşiler, dini veya laik feodal prensler ve artan ticari faaliyetlerin ortaya çıkardığı kent-devletleri arasındaki mücadele, 11. ve 19. yüzylllar arasındaki dönemde Avrupa tarihinin özünü teşkil etmektedir (Sander, 1998, s. 70). Rönesans ve reform hareketleriyle birlikte hızlı bir dönüşüm sürecine giren Avrupa'nın, yüzyıllar boyunca bahsi geçen bu güç odaklarının iktidar mücadelesi alanı olduğu ve pek çok tarihi gelişmeye tanıklık ettiği görülmektedir. Bu genel tablonun yanında 16. ve 17. yüzyllar Avrupa'sının siyasal ve sosyal yapısı ele alındığında ise dikkatle irdelenmesi gereken bazı temel olgular olduğu görülmektedir.

$\mathrm{Bu}$ olguların başında, 1348 yllında ortaya çıkan ve 18. yüzyılın sonlarına kadar farklı coğrafyalarda yinelenerek etkisini sürdüren veba hastalığı yer almaktadır. 1348-1350 yılları arasındaki büyük veba salgını Kuzey Batı Avrupa nüfusunun muhtemelen yarısından fazlasını ölümüne sebep olmuştur. Avrupa kıtası, hastalıktan önceki nüfusuna yüz elli yıl sonra 16. yüzyılın başlarında ulaşabilmiş, ancak bu dönemden sonra da zaman zaman on binlerce insanın ölümüne yol açan bölgesel veba salginlarıyla karşılaşılmıştır. Boccaccio'nun Decameron adlı eserine yazdığı sunuşta Teksoy, hastalığın Avrupa'daki sosyal düzeni temelinden sarsarak Roma Katolik Kilisesi'ne büyük bir darbe vurduğunu, milyonlarca insanın hayatını kaybetmesinin ortaya çıkardığı travmatik durumun ve günlük hayatın belirsizliğinin, toplumsal yapı üzerinde etkili olan ahlaki pratikleri çöküntüye uğrattığı ifade etmektedir (Boccaccio, 2002, s. 9-10). Hastalık karşısında çaresiz kalan Avrupa toplumlarının, çözümü astroloji ve teolojide aradığı ve buna bağlı olarak büyücülük ve medyumluk gibi Ortaçağ uğraşlarında büyük bir artış yaşandığı dikkati çekmektedir (Gümüş, 2011, s. 144). Bu dönemde Avrupa'nın farklı bölgelerinde dilencilerin, cüzzam hastalarının, farklı dini grupların ve yabancıların da dâhil olduğu toplumsal azınlıklar, hastalık sonucu yaşanan ölümlerin sorumlusu kabul edilerek cezalandırılmış, saldırıya uğramış ve öldürülmüşlerdir (Colet, Anna vd., 2014, s. 64).

17. yüzyılda Avrupa'nın siyasal ve sosyal yapısını şekillendiren bir diğer önemli gelişme, 1618-1648 yılları arasında gerçekleşen ve Otuz Yıl Savaşları olarak adlandırılan mezhep savaşlarıdır. Avrupa'da 17. yüzyılın sonralarında dini motivasyon unsurlarının toplumsal yapı üzerindeki etkisi zayıflayana kadar, Katolik ve Protestanların büyük bölümü birbirilerini şeytanın uşakları olarak görmüşlerdir (Lerner, Meacham \& Bur- 
ns, 1988, s. 515). Bu durum Avrupa'da uzun yillar boyunca süren mezhep savaşlarının özünü teşkil etmektedir. Ancak Otuz Yıl Savaşları'nı mümkün kılan ortamın oluşmasında Avrupa devletleri arasındaki egemenlik mücadelesi, siyasi ve politik çıkarlarının en az dini çatışmalar kadar etkin bir role sahip olduğu görülmektedir. Özellikle kendi hegemonyasını çevresindeki devletlere kabul ettirme arzusunda olan Fransa ile Fransa'nın bu ideallerinin karşısındaki en büyük engel olarak görünen Habsburg Hanedanlığı arasındaki çekişme, Otuz Yıl Savaşları'nın gidişatını şekillendiren temel unsurlardan biri olarak gösterilmektedir (Tanilli, 2004, s. 254). Otuz Yıl Savaşları, Protestanların zaferi sonucu 1648 tarihli Westphalia Barışı ile sona ermiştir. Westphalia Barışı'nın Avrupa'da daha önce gerçekleştirilen dini nitelikli uluslararası toplantılardan farklı olarak devlet, savaş ve iktidar sorunlarının müzakere edildiği laik bir konferans olduğu kabul edilmektedir. Konferansta papalık temsilcisi dinlenilmediği gibi, antlaşma Papa'ya da imzalatılmamıştır. Antlaşma ile Roma Katolik Kilisesi'nin gücü tam anlamı ile sınırlandırılmış ve Kutsal Roma İmparatorluğu'nu parçalanmış olduğu uluslararası hukuk bakımından doğrulanmıştır (Sander, 1998, s. 89). Bu durumun Kilise'nin Avrupa'daki siyasi etkinliğini büyük oranda azalttığı ve merkezi monarşilerin kıta Avrupa'sındaki konumunu güçlendirdiği görülmektedir.

Avrupa'da 17. yüzyılda siyasal ve sosyal yapıyı biçimlendiren önemli unsurlardan biri de feodal beyliklerin yıkılması ve mutlak monarşilerin Avrupa'daki egemen devlet yapilanması haline gelmesidir. Bu dönemde mutlak, sinırsız, tek, bölünmez ve devrilmez niteliğiyle monark (hükümdar), klâsik egemenlik anlayışının en iyi temsili olarak görülmektedir. Egemenliğin bu anlamıyla uluslararası alanda kabul edilmesi ise Westphalia Barışı (1648) ile gerçekleşmiştir. Westphalia modeli, dünyanın egemen devletlerden oluştuğu görüşüne dayanmakta ve devletin kendi sinırları içinde, devlet üstü bir otoritenin varlığını dışlamaktadır (Arslanel \& Eryücel, 2013, s. 26). Bu bağlamda XIV. Louis dönemi ile başlayıp 1789'da Fransız Devrimi ile son bulan dönem Avrupa'da Mutlakiyet Çağı (Age of Absolutism) olarak kabul edilmektedir (Lerner, Mecham \& Burns, 1988, s. 599).

Ken Russell'ın The Devils filminde 17. yüzyllın birinci yarısındaki Fransa resmedilmektedir. Bu dönem XIII. Louis ve onun başbakanı Kardinal Richelieu tarafından Fransa'da mutlak monarşinin kesin olarak hâkim kılındığı dönemdir. Bu yüzyılda Kardinal Richelieu'nün raison d'etat (ulusal çıkarlar) doktrini, Fransa'nın iç ve dış siyasetteki tavrını şekillen- 
diren temel olgu olmuştur. Richelieu'nün başbakanlığı döneminde (16241642) kuruluşunu tamamladığı siyasal sistem Fransa'da yaklaşık yüz elli yll boyunca krallık iktidarının sürmesine imkân tanımıştır. Richelieu, iç siyasette ilk olarak aristokratların üstünlüğünü yeniden sağlamış, sonrasında merkezi hükümeti güçlendirmek için Fransa'nın güneyindeki Huguenot Cumhuriyeti'ne son vermek amacıyla, sekiz yıl süren bir askeri harekât gerçekleştirmiştir. 1629 yllında Huguenot'un asıl kalesi olan La Rochelle'nin ele geçirilmesiyle Huguenot direnişi sonlandırılmış ve silahlı güçleri dağıtılmıştır. Ayrıca Katolik olmalarına karşın merkezi hükümete karşı isyankar tavır sergileyen aristokratlara boyun eğdirebilmek için feodal şatolar yıkılmıştır. Richelieu, hükümete karşı her türlü muhalefet girişimini komplo damgası vurarak bastırma yöntemini seçmiş, böylece merkezi iktidarın etkinliğini arttırmıştır. Dış politikada da ulusal sınırlar içindeki tavrını devam ettiren Richelieu, Kutsal Roma Kilisesi'ne bağlı Katolik bir kardinal olmasına karşın Otuz Yıl Savaşları sırasında Fransa'nın Protestan birliğinin yanında yer almasını sağlamıştır. Böylece Otuz Yıl Savaşları sonrasında Fransa Avrupa'daki yegâne siyasi güç haline gelmiştir (Tanilli, 2004, s. 222-227). Dönem Avrupa'sının siyasi yapısına ilişkin bu gelişmeler yanında sosyal alanda hayat bulan kimi unsurların varlığı da filme konu olan tarihsel periyodun niteliklerinin anlaşılması açısından önemlidir.

17. yüzyllda son derece yaygın olan şüphecilik ve inanç arasındaki gerilim, yeni bir görüngü ortaya çıkarmaktadır: Hıristiyanlığa inançsızlığın ve Hıristiyan Şeytan'ına inancın tuhaf bir karışımı olan kara ayin. Kara ayin için gerekli ortam, gerek cadılık gerekse şeytani gücün bilinçdışı rahatsızlıklarla, özellikle cinsel sapkınlıklarla yakından ilişkili olduğu, şeytanlarca ele geçirilişe ilişkin çok sayıdaki söylenti tarafından yüzyıllardır hazırlanmaktadır (Russell, 2001, s. 125-126). Böylece normdan sapma ve farklı bir gerçekliğin sözcülüğünü yaparak ritüel yoluyla bunu gerçek kılma söz konusu olmuştur. The Devils filmine konu olan Loudun'daki olay da bu çerçevede değerlendirilmektedir:

Fransa'da Loudun ve Louviers'deki rahibelerin İblis tarafindan ele geçirilmesi olayında, İblisin güçleri ve insan cinselliği, kolektif isteri ve sanrılardan oluşan bir atmosfer içinde son derece zeki bir stratejiyle politik amaçlar için kullanılmıştır. Loudun'daki Ursuline manastırındaki rahibelerin İblis tarafından ele geçirilmesi öyküsü oldukça iyi bilinmektedir. Histeri, Urbain Grandier adlı bir papazın çevresinde patlak verir. Grandier cinsel yönden bir özgürlükçüdür ve sivri zekâsı 
nedeniyle birçok düşman kazanmıştır. Bu düşmanlardan bazıları onu, rahibeleri baştan çıkarmak ve İblis tarafından ele geçirilmelerine yol açmakla suçlayarak mahvetmeyi planlarlar. Rahibelerin en azından bir bölümü, şeytanlar tarafından taciz edildiklerine inanmaktadırlar. Louviers manastırında, rahibe olmadan önce günah çıkarttığı papaz tarafından tecavüze uğrayan bir rahibe demonlar tarafından ele geçirilme olayının odak noktası olur. Bu tür olayların, cadılıkla ilgili olaylardan ayrılan özelliği, dikkatlerin cinsellik üzerinde yoğunlaşması ve olaylara rahiplerin de bulaşmasıdır- ki, bu unsurlar yeni ortaya çıkan kara ayinlerde de merkezi bir nitelik kazanırlar; çünkü Katolik inancında hiçbir şey, bir rahibin başkanlığı altındaki kilisenin kutsallığının cinsel sapkınlıklar için kullanılmasından daha büyük bir günah olamaz (Russell, 2001, s. 126-127).

The Devils ilmi, sosyal ve siyasal panoraması yukarıda aktarılan 17. yüzyıl Fransa'sında yaşanan gerçek bir olaydan esinlenilerek beyaz perdeye aktarılmıştır. 1634 yılında Loudun kasabasında bulunan St. Pierre du Marche kilisesindeki rahibelerin geceleri şeytanların odalarına gelerek onları taciz ettiğini söylemeleri üzerine Roma Katolik Kilisesi tarafindan yapılan soruşturma neticesinde peder Urbain Grandier büyücülük yaptığı gerekçesiyle suçlu bulunmuş ve yakılarak idam edilmiştir. Dönem Avrupa'sında benzerlerine sıkça rastlanılan bu dava, sonraki yıllarda siyasi içerikli bir olay olarak kabul edilmiş ve Urbain Grandier'nin, Kardinal Richelieu tarafindan desteklenen politik bir komplonun kurbanı olduğu konusunda genel bir kanı ortaya çıkmıştır.

\section{The Devils Filminin Analizi}

Filmin senaryosu Aldous Huxley'in 1952 yllında yayımlanan kitabı The Devils of Loudun ve John Whiting'in 1960 tarihli oyunu The Devils temel alınarak oluşturulmuştur. 17. yüzyıl Avrupa'sının kaotik ve karanlık ortamında yaşanan olay filmde çarpıcı bir biçimde ele alınmaktadır. Katolik kilisesi, veba ve mezhep savaşları sebebiyle büyük bir nüfus kaybı yaşayan dönemin Fransa'sında, feodal derebeylikleri ve farklı mezhepleri ortadan kaldırmaya çalışmakta, kapalı sur duvarları ardındaki, görece özerk ve dış saldırılardan muaf bölgelerin varlığına son vererek iktida-

1 Aldous Huxley, Urbain Grandier ve etrafındaki deli rahibeler olayında sanrı yaratan etkenin büyük bir olasılıkla çavdar kılçığı olduğunu, Loudun rahibelerinin gösterdikleri semptomların bu buğday paraziti zehirlenmesinin semptomlarına şaşırtıcı ölçüde benzediğini açıkladı. Gerçekten de bu kılçık zihni rahatsız ediyor ve saplantılara neden oluyordu (Huxley'den aktaran Messaide, 1998, s. 10). 
rını genişletmek istemektedir. Böyle bir ortamda merkezi otorite ve Katolik inancının tabu ve yasaklarına karşı çıkan peder Urbain Grandier (Oliver Reed), skolastik düşüncenin egemen olduğu acımasız Engizisyon mahkemesi koşullarında yargılanarak çeşitli işkencelere tabi tutulur ve Şeytan'la işbirliği yaparak rahibeleri taciz ettiği gerekçesiyle ateşte yakılarak öldürülür.

Film dönemin egemen yaşam pratiği, inanç sistemi ve Avrupa'yı kasıp kavuran veba salgınını görünür kılması açısından dikkat çekicidir. Toplumsal histerinin egemen olduğu bir ortamda, reformist bir peder olan Grandier, yakışıklılığının da etkisiyle bölgedeki pek çok kadının ilgisini çeker, bazı kadınlarla cinsel birliktelik kurar ve Katolik inancının rahipler için koyduğu evlenme yasağını ihlal eder. Peder Grandier'e göre, cinsellik doğal bir olgudur ve doğal olan Tanrısaldır. Grandier bu aşamada uygarlık sürecinin olağan görünen akışını kısmen dönüştürmeye çalışır. Elias'ın da vurguladığı gibi uygarlık süreci, temel içgüdülerin bastırılması üzerine de kuruludur:

Uygarlık süreci içinde cinsellik de yavaş yavaş toplumsal yaşantının sahne arkasına atılmış ve belirli bir toplumdışı alanla, dar aile çevresi ile sınırlandırılmıştır; cinsiyetler arasındaki ilişkiler bilinç düzeyinde de aynı şekilde sınırlandırılır, gizlenir ve "sahne arkasına" itilir. İnsan yaşamının bu alanı, sosyo-oluşumsal korkunun bir ifadesi olan sıkıntı duygusunun oluşturduğu bir hale ile çevrelenmiştir (2013, s. 295).

Dolayısıyla cinsellik üzerindeki denetimin, rahiplerin bireysel dünyevi iktidarının süreğenleşmesinin önünde bir engel olmasının yanında, toplumsal yaşamın sahne arkasına itilerek, suçluluk duygularını güçlü tutarak insani öze bir yabancılaşmaya yol açtığını söylemek mümkündür. Grandier'ye göre Kutsal Kitap'ta evlilik yasağına ilişkin hiçbir bildirim yoktur. Havarilerden bazıları evlenmiş, çocuk sahibi olmuştur. $\mathrm{Bu}$ da evlilik yasağının aslında Hristiyanlığın özünün bir sonucu değil, ona d1şarıdan eklenmiş, dolayısıyla bu eklenmişliğin politik bağıntılarını ifade eden doğal olmayan bir durum olduğu vargısına götürmektedir. Bu yanıyla Grandier Hristiyanlığın özü ile şimdiki var oluşu arasında bir açıklık ve uçurum olduğunu iddia eder ve tavrını Hristiyanlıktaki özden yana koyarak, bu öze dönüşü gerekli görür. Böylece Grandier ruhban sınıfı için konulan evlilik yasağına karşı çıkar. Dahası, bunu soyut bir tartışma nesnesi olmaktan çıkarak pratiğe döker ve annesi vebadan ölmüş Madeleine (Gemma Jones) ile sonu evliliğe varacak bir ilişki başlatır. İronik biçimde ilişkileri ona günah çıkarmak için gelen kadınların aşk itiraflarıy- 
la başlar. Grandier evliliğin iү̣i bekârlğ̆ın daha iүi olduğunu düşünen biri ise de, arzu ve isteklerini bastırmaz ve kendisine yapılan bu ilan-ı aşka, bedensel zevklerin giderilmesine onay verir. Gizli buluşmada da bu açık günahın yükünü taşımaya çalışan bu kadını önce reddetse de sonrasında âşık olur. Grandier, görüldüğünü bilmeden nikâhın hem kıyıcısı hem de damadı olur. Bu durum başlı başına aforoz edilmek için bir nedendir ancak madalyonun bir de siyasi yönü bulunmaktadır: Grandier merkezi otoritenin kararlarına direnmektedir. Grandier'nin yaşadığı Loudun'un özerkliğinde önemli bir rolü olan, vali Georges de Sainte-Marte vebadan ölmüştür. Valinin ölümü Loudun'un özerkliği bakımından ciddi bir otorite boşluğuna yol açsa da, Grandier bu boşluğu doldurmaya çalışır ve kentin surlarını yıkmaya gelen Baron'a (Dudley Sutton) silahlı birliklerle karşı durur. Ylkımın durdurulmasında, valinin ölmeden önce kendi yerine yeni vali bir atanıncaya kadar Grandier'yi yetkilendirmesi de etkili olur. Baron de Laubardemont yıkım emrini Kardinal Richelieu'dan almıştır. Bölge nüfusunda Protestanlar Katoliklerin nüfusunu iki kat geçmiştir ve Protestanların sadakatinin gelecekte isyankar hareketlere dönüşüp dönüşmeyeceği belirsizdir. Dolayısıyla her şeyden önce nüfus sorunları ve politik denge bu yıkımın yapılması için bir gerekçe olur. Kardinal'in amacı savaştan kaçan Protestanlara sadakatleri karşılığında güvenli bir mekân sağlayan özerk, küçük, surlarla çevrili alanların merkeze bağlanması, buraların Katolik Kilisesi için güvenli hale getirilmesidir. Grandier bu sürecin sonunun bölgenin Katolisizm dişı unsurlar için güvensiz hale getirilmesi ve özgürlüğün kaybı olduğuna emindir. Film bu saldırı kararlarının alınmasındaki tiүatromsu havayı serimler. Kral bölgelerin merkeze bağlanması emrini siyah kuş kostümü giydirilmiş Protestan kuşlarını öldürürken verir. Buna karşın kale duvarlarının yıkılmaya çalışılması olarak belirginleşen ilk saldırı Grandier tarafından savuşturulmuştur; Kralın sözü burada bağlayıcıdır. Kral eğer yapabiliyorsa diğer kentleri ele geçirmesini ama Loudun'a dokunmamasını söyler. Grandier'nin hamlesi onu Kardinal Richelieu ve Baron de Laubardemont için etkisiz kılınması gereken bir kişi konumuna sokar. İçinde yaşadığı Loudun'un surlarının yıkılmasını engellemeye çalışan ve kasabanın ruhani lideri olarak toplumu bu amaç uğrunda hareket etmeye yönlendiren Grandier, din, aristokrasi ve siyaset kurumunun şimşeklerini üzerine çeker ve feci bir şekilde cezalandırılmakla karşı karşıya bırakılır.

Peder Grandier dönemin şartlarına göre birçok yönden aykırı bir kişiliktir. Kadınlarla girdiği ilişkiler, birlikte olduğu Philippe (Georgina Hale) adlı kadının hamilelik iddiası ve Grandier'nin kilisenin evlilik yasa- 
ğını ihlal etmesi buna örnektir. Tüm bunlara Grandier'nin başrahibe Jeanne tarafından şeytanla ilişkilendirilmesi iftirası eklenir. Jeanne onu ilk kez eski Vali'nin cenazesinde görür. Cenazede genç rahibeler çoktan gizlice yerlerini almışlardır. Onu izleyen bir rahibe bağırır: "Dünyadaki en yakışıklı adam. O, Cehenneme gitmeye değer bir adam." Jeanne de genç rahibeleri gönderdikten sonra gizli bölmeye gidip onu izler. İlk gizli bakış bir esrime hali ile desteklenir. Rahibe düşünde Grandier'yi tıpkı İsa gibi suyun üzerinde yürürken görür. Altın saçlı bir bakire olarak onun yanına gider ve saçlarıyla ayağını siler. Sonradan esen rüzgâr saçlarını dağıtır ve sırtındaki çıkıntıyı görünür kılar. Dalga geçenlerin gülüşü ile birlikte Ne kadar güzelim diye söylenir. Kamburundan kurtulmuş, imgelemindeki ideal varlığı ortaya çıkmıştır. Dolayısıyla ilk çatışma gerçeklikteki sürecin ters görünümüdür. Çirkin kamburuna karşı güzeldir. Saygı duyulan bir konumda olmasına karşın hayalinde bile alay edilir. Grandier, Jeanne için kendi gerçekliğinden, eksiklikleri ve fazlalıkları'ndan kurtulduğu, kendi ideal birliğine ulaştığı bir kutsal figür halini alır. Çok geçmeden âşık olduğu Grandier'e mektup yazar. Onu bir lider olarak görmektedir. Ancak çok geçmeden Grandier'nin Madeleine ile evlendiği söylentileri duyulur. Jeanne'ın rahibe olarak manastıra katılımını reddettiği Madeleine'ye yönelik nefreti, imgelediği ideal koca ve kurtarıcı İsa'yı ondan önce almış olmasıdır. Keşke ilk beni görseydi diye söylenir Rahibe. Yeni önderin gelmesini beklerken, yani Grandier'yi beklerken, karşısında yardımcısı Peder Mignon'u bulur. Mektubunda ona kilisenin idaresini almasını söylemişse de Peder Grandier bunu reddetmiştir. Bu reddedilmişlik içerisinde ilk iftirasını yapar. Başrahibe Jeanne'nin iftirası Grandier'e komplo kurmaya çalışan Kardinal Richelieu, Baron de Laubardemont ve Grandier ile çıkarları çatışan diğer kesimlerin için kaçırılmayacak bir firsat sunar. Grandier'nin reformist düşünceleri ve politik özerklik yönündeki çabaları kendisine karşı geniş bir cephenin kurulmasının yolunu açmaktadır. Grandier'nin trajedisi ve kahramanlaşması da bu eksende, tek başına dönemin egemen güçlerine karşı durma iradesiyle şekillenmektedir. Dolayısıyla onun durumu, tıpkı İsa gibi yürüdüğü yolun nereye gittiğini bilen, günahı yüklenmiş bir figür olarak belirmesine imkân tanır. Bundan sonrası onun kendi Havarilerini, Romalı yöneticilerini, Yahudileri ve Yahuda'sını bulması, onlarla karşılaşmasını metaforik bir düzlemde ortaya koyar. Böylece filmin yönetmeni bir yandan Hristiyanlığa karşı sert bir eleştiri getirirken, kahramanı tarihsel bir figür olarak yeniden oluşturur; onun şahsında Hristiyanlığın dinsel ve mitsel yolculuğunu yineler. 
Film yargılama sürecinin ve itirafların gayri ahlaki oluşu konusunda kesin bir söyleme sahiptir. Madeleine'nin annesine de işkence eden cerrah ve kimyacı yeniden hazırdır. Sistematik biçimde Jeanne'ın bedeninde bir iz bulmaya çalışırlar. Böylece bedenlerinde şeytana ait nesneleri olan insanlar araştırılacaktır. Sonunda Grandier sözü alındığında suçlamalar hızla oluşturulur ve yargılama için gerekli zemin hazırlanır. Madeleine ertesi gün Grandier'den kente gitmemesini ister. Grandier ise şehrin kurtulması için gitmesi gerektiğini söyler. Grandier umut, aşk ve nefreti rahibeden kendisine uzanan hüsranın nedenleri olarak sıralar. Kendini tanrıya teslim etme, zihnin köşelerinde kalmış, çıkmayı bekleyen arzular, bastırma ile devam eden ceza ve sonunda imgenin gerçekliğin yerini alması söz konusudur. En gizli, dile getirilmemesi gereken arzular esrimelerle kendini gösterir. Sonrasında ise başrahibeye yapılan işkenceye itiraz eden genç rahibeler hedef tahtasına yerleştirilir. Ormanllk alanda, çukurun içinde Kilise'nin iradesine direnmekle suçlanırlar. Dolayısıyla şiddetin hizaya getirici gücü sürekli biçimde kullanılır. Onlar ölümlerini beklerken Rahip Barre'nin ihsanıyla karşılaşıp daha da büyüyecek olan tiyatro oyununun parçası olurlar. Kurtarılan rahibeler Barre'dan talimatlarını alırlar. İhlal gerçekleştirilmelidir. Küfredecek, bağıracaklardır ve yaptıkları işlerden sorumlu tutulmayacaklardır. Toplu seks ayini başlar. Böylece Barre kovacağı şeytanları, önce nesnelleştirir; görünür kılar. Sonrasındaysa onları çıkarmak için sistematik işkenceye ve sözün gücüne bel bağlar. Bu durumun ironik ve temelsiz oluşunu ise Conde dükü gösterir. Barre'ye kutsal emanet vererek şeytanların çıkarılmasını kolaylaştırır. Sonunda esrimelerle şeytan çıkar ancak ortada bir kutsal emanet yoktur. Tüm olan biten bir oyundur.

Filmde cinsel bastırılmışlık ve bu bastırılmışlığın kendini dışa vurma biçimleri yoğun bir şekilde işlenmekte ve bu olgu yaşananları birçok yönden etkilemektedir. XIII. Louis'nin transgender özelliklerine karşılık ruhban sınıfına uygulanan cinsel yasaklar, aristokratların görünüşte ahlakçılığına karşı gündelik yaşamlarının örüntülenme biçimindeki tutarsızlıklar, cinsel kimliklerin sürekli bir sınır hattında inşa edilmesine neden olmaktadır. Filmdeki merkezi karakterler olan Grandier ve Jeanne gibi kişilikler, yaşamlarını tabular üzerine inşa ettikleri öz ile biçim arasındaki sürekli çelişki yaşarlar. Kendini tanrıya adama beklenirken dünyasal koşullar sürekli bedensel hazzın olanak ve olanaksızlıklarını sunar. Özellikle rahibeler, Jeanne'ın ifade ettiği gibi sıklıkla aristokrat sınıfından gelmektedirler ancak bu kişiler yine sıklıkla evlenmek için yeterli çeyizi bulunmayan, varlıkları ailelerine yük olan adaylardan oluşmakta- 
dır. Dünya yaşamında çekilip manastıra kapanıyor görünseler de aslında arzularını bastırmışlar ve bu zorunlu kapanışı bir kader olarak benimsemişlerdir. Bununla ilişkili olarak da kendi bedenlerine, bedensel arzularına ve gerçek dünyaya yabancılaşırlar. Grandier onlar için giderek bir fetiş nesnesi olur ve onun arzu edilen imgesiyle doyum elde etmeye uğraş verirler. Böylece filmdeki hemen tüm kişiler geçici olarak arzu nesnelerine ulaşabilseler de temelde ondan uzak kalırlar, bunun gerilimini yoğun biçimde yaşayıp krize girerler. Bu durumun en uç biçimi rahibe Jeanne'da yaşanır. Grandier'yi giderek fetişe dönüştürür ve imgeleminde onunla birlik olarak günah işler, bunun kefaretini öder. İmgeleminde kendisi de güzel ve alımlı bir kadın olsa da gerçeklikteki kötürüm hali onun krizlerini şiddetlendirir ve Grandier'nin yıkımının nedeni olur. Jeanne sürekli biçimde sevgi ve aşk aradığı için otoriteyi ve var olan toplumsal normları ahlaki düzeyde sorgulamaz. Sistematik işkence ile birlikte hızla Baron'un istediği ifadeleri verir; sonunda Grandier idam edilmiş ve kent surları yıkıldığında kendisini ziyarete gelen Baron Laubardemont'un önünde kendi iblislerini temizlemektedir. Dolayısıyla otoriteyi hızla özümseyip, onun istediği gibi olabilmektedir. Grandier için ise cinselliğin doğal yönü ile onun tabu olarak sunuluşu arasındaki çelişki teolojik değil, dünyasal bir sorun olarak kavranır ve Grandier kendisine yapılan tüm işkencelere rağmen kefaretini öder. Baron de Laubardemont'a karşı kendini "Bir zamanlar erkektim, kadınları sevdim, gücün tadını çıkardım" şeklinde savunmaktadır. Genç rahibeler ise bekledikleri cinsel taşkınlık ya da rahatlığı Rahip Barre sayesinde elde eder. Gerekli tövbe yapılsa da, şeytanın nesnelleştirilmesi, bastırılan cinsel arzuların ortaya çıkarılması gerekir. Grandier buna karşılık Tanrı'nın evini sirke çevirdiğini, hizmetçilerini de palyaçolara döndürdüğünü, insanları yok etmek için baştan çıkardığını söylese de durum çok fazla değişmez. Film açık bir şekilde masumiyetin ya da masum kalmanın tabu kaldığı bir çerçeve, bir dünya sunar ve bunun yanlışlığını hissettirir.

Grandier kendisine karşı kurulan komployu öngörmektedir ancak yine de tarihsel rolünü oynamaktan geri durmamaktadır. Grandier eylemlerinin sonuçlarına katlanmaya hazırdır ve bu filmde birkaç kez vurgulanarak anlatılmaktadır. Bu durum Grandier'nin idealize edilerek sunulması bağlamında anlaşılır olmaktadır. Yargılanma sürecinde kendisine karşı kurulan komplonun politik niteliğinin farkında olan Grandier düşüncelerini savunmaktan geri durmamaktadır, ağır işkencelere rağmen direniş̧̧i tavrını sürdürmektedir. Mahkeme tarafından Şeytanla iş birliği yapmakla yargılanan Grandier'nin, yakılarak öldürülmesine 
karar verilir. Verilen infaz kararı sonrası Baron de Laubardemont ve Peder Barre, Grandier'yi itirafa zorlamaktadır. Grandier'nin üzerinde psikolojik ve fiziksel şiddet uygulatır. Ağır işkencelerin görünürdeki amacı Grandier'nin ruhunu kurtarmaktır. Oysa sorun merkezi iktidar ve ruhban sınıfın oluşturduğu egemen blokun ideolojik hegemonyasının tesisi ile ilgilidir. Grandier'nin düşüncelerinden taviz vermemesi egemen ideolojiyi zedeleyebilme potansiyeline sahiptir, ruhun kurtarılması ise işin kıllfı olarak kullanılmaktadır. Grandier için yaşamını ve düşüncelerini savunmak dışında itiraf edecek bir şey yoktur. Bu nedenle, olabildiğince işkencelere göğüs germektedir. İnfazın hemen öncesinde, rahibe Jeanne ile göz göze geldiğinde ona "çektiklerime ve düştüğüm hale bir bak ve aşkın anlamını gör" diyerek seslenir. Grandier bu sözlerle insanın amaçları için bedel ödemesi gerektiğini ve kendisinin bu bedeli ödediğini dile getirmektedir. Nitekim Grandier yakılırken dahi düşüncelerini seslendirmeyi sürdürür. Peder Grandier yakılırken izleyenlere şöyle der:

Şehrinizi bu kadar savunduğum için beni affedin; yanarken bana bakmayın, şehrinize bakın, şehriniz yok olursa özgürlüğünüz de yok olur. Özgür olarak kalacaksanız savaşın, onlara karşı savaşın ya da köle olun.

Dolayısıyla filmde ana kahraman, kendisine sunulanin trajik niteliğinin bilincinde, acının dayanılmazlığının farkında olarak bu sürecin onun kimliğinin ayrılmaz bir parçası olduğunu bilerek yolculuğuna devam eder. Bu yüzden filmdeki en az yabancılaşmış insanın Grandier olduğunu, onun sadece kendisinin değil, başkalarının eyleminin özsel niteliğinin ve temel yönlendirici itkisinin (politik ve toplumsal çatışmalar, nüfus dengesi vb.) ne olduğunu bildiğini söylemek mümkündür. Kendi ediminin sonuçlarını bilir, bunu kabul eder ve kendi kimliğini bu bilinçlilik üzerine inşa eder.

İnançlı kişinin inancını yayma isteği aynı zamanda daha genel bir birlik istencinin dişavurumudur. Ayrıksı ve gruptan farklılaşmış olan, olmuş olana değil, potansiyel olarak var olabilene gönderme yapar ve farklıyı temsil ettiği sürece de birliğe zarar verir. Ayrıksı olanın varlığı baskın grup için bozucu etki yaratır. Ayrıksılaşan birey için de bütünlük duygusunun yitimi, tecrit edilmişlik giderek kendi kimliğinin kurucu unsuru olur. Filmin sonunda kendi gücünü geçici bir süre de olsa gösteren iktidar arzuladığı birliği elde etmiş görünse de, filmin söyleminde bu özgürlüğün kaybedilişi ve köleleşme, dinin politik bir araç olarak kullanılması süreğenleşmesi anlamına gelmektedir. Grandier'ye uygulanan işkence ve infaz farklı amaçlara hizmet eden bir görünüm sergiler. Önce- 
likle Hristiyanlıktaki rahiplerin evlenmeyeceklerine dönük genel bir ihlali gösterir. Rahibeler de dâhil pek çok kadının gözünde bir arzu nesnesi olan Peder Grandier bu ilkeyi ihlal ederek aslında sınırı tam olarak geçmiş sayılmaz. Sınırı geçtiği nokta Loudun'un işgali önündeki en büyük engel olmasıdır. Bir kez bu durum belirginleşince bastırılmış arzularıyla kıvranan rahibelerin şeytan tarafından aldatılmışlıkları sadece bir gerekçe olacaktır. Sistematik işkenceden geçenlerin, bir süre sonra gerçekten de uğradıkları deformasyonla birlikte damgalanması, şeytanlaşması ve olması istenildiği gibi davranmaları benzerlerine sıklıkla rastlanılan bir olgudur. Bu yüzden rahibin ve rahibenin işkence edilerek itirafa zorlanması işgalin hedeflenmesi ve işgalcilerin özgürlüğü sonlandırması gibi bir anlamı ifade eder ve filmin sonunda bedenin yanışıyla birlikte işgal de tamamlanır, surlar yıkılır.

The Devils'da yer alan en çarpıcı unsurlardan biri Peder Urbain Grandier ve Rahibe Jeanne'e yapılan işkencelerin resmedildiği sahnelerdir. Başlangıçta izleyici için oldukça rahatsız edici ve abartılı gelebilecek olan işkence sahneleri aslında büyük oranda dönem Avrupa'sının gerçekleriyle örtüşmektedir. Aksan, Ortaçağ Avrupa'sında cadılık ve büyücülük vakalarıyla ilgili sorgu süreçlerinin üç aşamadan oluştuğunu belirtmektedir. Birinci aşama iүi niyetli sorgulamadır. Bu aşama hâkim tarafından yöneltilen ayrıntılı sorulardan oluşmaktadır ve özellikle şeytanla birlikteliğin ve birleşmenin ayrıntıları istenir. İkinci aşamada büyücülük ile suçlanan birey hala bir itirafta bulunmadıysa korku yaratmak amacıyla işkence aletleri gösterilmektedir. Son aşamada ise suçluya şeytanla işbirliğini itiraf etmesini sağlamak amacıyla işkence edilmektedir. Vücudun çeşitli bölgelerine iğne batırılması, ayak ve parmakların çekiçle ezilmesi o dönemde kullanılan işkence yöntemleri arasında yer almaktadır (Aksan, 2013, s. 363-364). Bu bağlamda filmde Urbain Grandier ve Rahibe Jeanne'e yapılan işkenceler 15. ve 18. yüzyıllar arasında sıkça rastlanılan cadılık davalarında kullanılan sorgulama metotlarıyla büyük oranda benzerlik göstermektedir. Film bu yönüyle Katolik Avrupa'yı kendi geçmişiyle yüzleştirmektedir.

Filmde hem siyasi hem de dini otorite tarafindan sinırları belirlenen tabuların karşısında yer alan Grandier, bu tutumunun bedelini hayatıyla ödemiştir. Ancak korkunç işkencelere maruz kalmasına ve diri diri yakılarak öldürülecek olmasına karşın Grandier, inandığı yoldan asla geri dönmemiş, kendi düşüncelerine ihanet etmemiş, yıkımın ve toplumsal çürümenin zirveye ulaştığı bir dönemde özgürlüğün sembolü biçiminde 
resmedilerek mitleştirilmiştir. Bu idealizasyon ve mitleştirme yönetmenin ideolojik bakışının film dilindeki yansıması olarak tezahür etmektedir.

\section{Sonuç}

The Devils Ortaçağ'da yaşam, inanç ve sosyo-politik durum üzerine üretilmiş sıra dışı ve çarpıcı bir filmdir ve insanlık tarihinin bir aşamasında egemen siyasi güçlerin inançları bir silaha dönüştürmesini gözler önüne sermesi ve seküler bir siyasi yapılanmanın neden önemli olduğunu göstermesi açısından dikkate değer bir yapımdır. Bu bağlamda filmde muhalif olan, merkez yerine çevrede ve bağımsız olmayı isteyen, tabuları sorgulayıp bunu yaşamsal edimleriyle destekleyenler büyük bir yıkıma uğrasa da, izleyici için empati ve sempati nesnesi kaybedenler tarafında olduğu için Katolik merkezi iktidar uzun dönemli yenilgisinin belki de son zaferini kutluyor görünmektedir.

Film, Fransa özelinde Ortaçağ Avrupa'sını siyasi, sosyal ve dinsel atmosferiyle gözler önüne sermektedir. The Devils'in ana kahramanı Urbain Grandier aynı zamanda tarihsel bir kişiliktir ve dinsel tabu ve dogmalara karşı reformist bir mücadeleye girişmiştir. Grandier'nin vebalılara uygulanan sadistik tedavi yöntemlerine karşı çıkması, çeşitli dogmaları sorgulaması, mezhep çatışmalarına karşı olması, içinde yaşadığı döneme göre ileri görüşleri savunması günümüzün bakış açısıyla onu mitsel bir kahraman formuna sokarak yüceltmektedir.

Tarihsel bir dönemi konu alan filmde anlatılan sadece tarih ve geçmiş değildir. Film, tarihsel bir olayın, yönetmenin bakış açısıyla 20. yüzyıldan okunmasıdır; filmi tarihi bir olayı anlatmanın ötesinde önemli kılan da bu özelliğidir. Filmde temel olarak inancı güvenli bir liman olarak gören ve bu limana sığınmaya çalışan bireylerin içine girdikleri yabancılaşma çarpıcı bir şekilde gösterilmektedir. Dinselliğin hâkim bir ideoloji olarak yaşamsal pratiklere egemen kılınması, tabu ve dogmaların düşünceyi gölgelemesi, yabancılaşmanın yarattığı körleşme sürecini derinleştirmekte bu durum ise insanları içinden çıkamayacakları anaforlara sürüklemektedir.

The Devils temel olarak Hristiyanlığın ve özellikle Katolikliğin yol açtığı bir akıl tutulmasının ve Ortaçağ boyunca süren karanlığın çarpıcı bir eleştirisi olarak dikkat çekmektedir. Filmde egemen paradigma dışına çıkmaya çalışan, aykırı düşünen ve olabildiğince düşüncelerini hayata geçiren reformist peder Grandier'nin yönetmenin gözünde ideal bir kah- 
raman olarak resmedilmesi dikkat çekmektedir. Bu idealizasyona karşın Grandier de kendini tam olarak tabuların ve dogmaların esaretinden kurtaramamaktadır. Grandier'nin reformist çabaları kurtuluşu sağlamamiştır ve o Engizisyon mahkemesinin yargılaması sonucunda heretik ve sapkın olmakla suçlanarak yakılmıştır. Filmde Grandier'nin trajik sonu somut koşulların somut tahlilini yapmamasından çok kendisini bilinçli şekilde feda etmesine bağlanmakta ve böylece idealist bir anlayışla Grandier yüceltilerek kahramanlaştırılmaktadır.

The Devils Ortaçağ'da yaşanan bir olay üzerinden inanç sistemleri ve iktidar mücadelelerine odaklanmaktadır. Bu bağlamda cinsellik ve beden üzerinde kurulan tahakküm de konuyla bütünlük sağlamaktadır. The Devils'e konu olan insanlığın deneyimleri ve insanın insan üzerinde kurduğu tahakküm ve baskı biçimleri aradan uzun zaman geçmiş olsa da insanlık tarafından aşllmamıştır. The Devils'i önemli ve güncel kılan bu sorunların aşılamamış olmasıdır.

The Devils'in kapanış sahnesinde Grandier'nin eşi Madeleine, Grandier'nin küle dönmüş kalıntıları önünde perişan halde görünür ve sonra yıkık surların enkazını aşarak Loudun'un dışına çıkar. Sonu beli olmayan beyaz zeminli uzun bir yolda yürümeye devam eder. Bu sahnedeki metaforik unsurlar insanlığın, acılarına ve yaşanan olanca karanlığa karşın yürüyüşünü sürdürmekten vazgeçmeyeceğini ifade etmektedir.

\section{Kaynakça}

Aksan, Y. (2013). 1450-1750 Yllları Arasında Avrupa'da Cadılık. Tarih İncelemeleri Dergisi. 28 (2) s. 355-368.

Boccaccio, G. (2002). Decameron. Cilt I (Çev. R. Teksoy). İstanbul: Oğlak.

Colet, A., Santiveri, J.X.M., Ventura, J.V., Saula, O. \& Galdàcano, M.E.S. (2014). The Black Death and It's Consequences for the Jewish Community in Tarrega: Lessons from History and Archeology. The Medieval Globe Journal, 1(1), s. 63-97.

Cüceloğlu, D. (2006). İnsan ve Davranışı (15. Baskı). İstanbul: Remzi. Eliade, M. (2001). Mitlerin Özellikleri (2. Baskı). (Çev. S. Rifat). İstanbul: Om.

Elias, N. (2013). UYgarlık Süreci. Cilt 1 (7. Baskı). (Çev. E. Ateşman). İstanbul: İletişim. 
Freud, S. (2004). UYgarlık, Toplum ve Din (Çev. E. Kapkın). İstanbul: Payel.

Freud, S. (2012). Dinin Kökenleri (2. Baskı). (Çev. A. Tekşen). İstanbul: Payel.

Fromm, E. (2006). Sağlıklı Toplum (4. Baskı). (Çev. Y. Salman. \& Z. Tanrısever). İstanbul: Payel.

Gümüş, T. (2011). Avrupa'da Kara Ölüm ve Dönem Kronikleri. Ç. Ü. Sosyal Bilimler Enstitüsü Dergisi, 20(1), s.139-164.

Hilav, S. (2008). Felsefe Yazıları (4. Baskı) İstanbul: YKY.

Kierkegaard, S. (2013). Kaygı Kavramı (7. Baskı) (Çev. T. Armaner). İstanbul: İş Bankası.

Lerner, E. R., Meacham, S \& Burns, E. M. (1988). Western Civilization. (Eleventh Edition). Londra: W. W. Norton \& Company Inc.

Ludovici, A. M. (2011). Nietzsche Hayatı ve Eserleri (Çev. D. Çimiçin). İstanbul: Parşömen.

Marshall, G. (2005). Sosyoloji Sözlüğü (Çev. O. Akınhay \& D. Kömürcü). Ankara: Bilim ve Sanat.

Marx, K. \& Engels, F. (2013). Alman İdeolojisi (2. Baskı). (Çev. T. Ok \& O. Geridönmez). İstanbul: Evrensel.

Marx, K. (2011) . 1844 El Yazmaları - Ekonomi Politik ve Felsefe (Çev. K. Somer). Ankara: Sol Yayınları.

Messadie, G. (1998), Şeytanın Genel Tarihi (Çev. I. Ergüden). İstanbul: Kabalc1.

Nietzsche, F. (2008), Deccal Hristiyanlığa Lanet (Çev. O. Aruoba). İstanbul: İthaki.

Nietzsche, F. (2004). Wagner Olayı, Nietzsche Wagner'e Karşı (2. Baskı). (Çev. M. O. Toklu). İstanbul: Say.

Öz, E. (2006). Yabancılaşma, F. Başkaya (Ed.), Kavram Sözlüğü II, Söplem ve Gerçek (s. 595-603). Ankara: Maki Basın Yayın.

Robinson, D. (2000). Nietzsche ve Postmodernizm (Çev. K. H. Ökten). İstanbul: Everest.

Russell, J.B. (2001). Mephistopheles Modern Dünyada Şeytan (Çev. N. Plümer). İstanbul: Kabalc1.

Russell, K. (Yönetmen). (1971). The Devils [Film]. ABD, BK: Russo. 
Sander, O. (1998). Siyasi Tarih: İlkçağlardan 1918'e. Ankara: İmge.

Simmel, G. (2009). Bireysellik ve Kültür (Çev. T. Birkan). İstanbul: Metis.

Ülken, H. Z. (1969). Sosyoloji Sözlüğüu. İstanbul: Milli Eğitim.

Tanilli, S. (2004). Yüzyılların Gerçeği ve Mirası: 16.-17. Yüzүıllar Kapitalizm ve Dünya. İstanbul: Adam.

Timuçin, A. (2004). Felsefe Sözlüğü. İstanbul: Bulut. 